Article

\title{
Biohydrogen Fermentation from Sucrose and Piggery Waste with High Levels of Bicarbonate Alkalinity
}

\author{
Jeongdong Choi ${ }^{1}$ and Youngho Ahn ${ }^{2, *}$ \\ 1 Department of Environmental Engineering, Korea National University of Transportation, \\ Chungju 380-702, Korea; E-Mail: jdchoi79@gmail.com \\ 2 Department of Civil Engineering, Yeungnam University, Gyeongsan 712-749, Korea \\ * Author to whom correspondence should be addressed; E-Mail: yhahn@ynu.ac.kr; \\ Tel.: +82-53-810-3511; Fax: +82-53-810-4622.
}

Academic Editor: Thomas E. Amidon

Received: 24 November 2014 / Accepted: 23 January 2015 / Published: 2 March 2015

\begin{abstract}
This study examined the influence of biohydrogen fermentation under the high bicarbonate alkalinity (BA) and $\mathrm{pH}$ to optimize these critical parameters. When sucrose was used as a substrate, hydrogen was produced over a wide range of $\mathrm{pH}$ values (5-9) under no BA supplementation; however, BA affected hydrogen yield significantly under different initial $\mathrm{pHs}(5-10)$. The actual effect of high BA using raw piggery waste ( $\mathrm{pH} 8.7$ and $\mathrm{BA} 8.9 \mathrm{~g} \mathrm{CaCO}_{3} / \mathrm{L}$ ) showed no biogas production or propionate/acetate accumulation. The maximum hydrogen production rate $\left(0.32 \mathrm{~L} \mathrm{H}_{2} / \mathrm{g}\right.$ volatile suspended solids (VSS)-d) was observed at $\mathrm{pH} 8.95$ and $3.18 \mathrm{~g} \mathrm{CaCO}_{3} / \mathrm{L}$. BA greater than $4 \mathrm{~g} \mathrm{CaCO}_{3} / \mathrm{L}$ also triggered lactate-type fermentation, leading to propionate accumulation, butyrate reduction and homoacetogenesis, potentially halting the hydrogen production rate. These results highlight that the substrate with high BA need to amend adequately to maximize hydrogen production.
\end{abstract}

Keywords: bicarbonate alkalinity; biohydrogen fermentation; sucrose; piggery waste; $\mathrm{pH}$; homoacetogenesis

\section{Introduction}

Hydrogen is a future sustainable and clean renewable energy carrier because it has a high energy yield and produces only water as the final product. A hydrogen society for sustainable development 
has been already started and well-established with a growth rate of 5\%-10\% per year overall [1]. Hydrogen is produced commercially by thermocatalytic gasification or electrolytic process, which is quite energy intensive, as well as by microbial hydrogen fermentation. Microbial hydrogen production through the direct fermentation of organic wastes is one of the potential technologies for producing renewable hydrogen that couples the need for waste reduction and byproduct recovery, simultaneously. On the other hand, it is unclear if the technology can be developed to provide a high hydrogen yield and become economically competitive with gasoline or with alternative hydrogen production.

In fermentation approach to biohydrogen production, the main technical barriers include the low molar yield of hydrogen, byproduct acid accumulation and feed stock cost, etc. Among them, the relatively low molar yield of hydrogen from organics is the most undesirable barrier, resulting from the simultaneous production of waste organic acids and solvents. Although $1 \mathrm{~mol}$ of glucose can theoretically produce 12 mol of $\mathrm{H}_{2}$ (1.4 L H $\mathrm{H}_{2} / \mathrm{g}$ chemical oxygen demand (COD) @ standard temperature and pressure (STP), as the theoretical maximum), as shown in Equation (1), the biological pathways maximally yield only $4 \mathrm{~mol}$ of $\mathrm{H}_{2}$ per mole of glucose $\left(0.467 \mathrm{~L} \mathrm{H}_{2} / \mathrm{g} \mathrm{COD}, 0.333 \mathrm{~g} \mathrm{COD} 2 / \mathrm{g} \mathrm{COD}\right)$ @STP [2,3]. Most studies have reported a molar yield of $2\left(0.233 \mathrm{~L} \mathrm{H}_{2} / \mathrm{g} \mathrm{COD}, 0.167 \mathrm{~g} \mathrm{COD} 2 / \mathrm{g}\right.$ COD)@STP or less [4]:

$$
\text { Glucose }+12 \mathrm{H}_{2} \mathrm{O} \rightarrow 6 \mathrm{HCO}_{3}^{-}+6 \mathrm{H}^{+}+12 \mathrm{H}_{2}, \Delta G^{\prime}(\mathrm{kJ} / \mathrm{mol})=+3.2
$$

Laboratory studies were performed for fermentative hydrogen production using actual wastewater, and the results showed a much lower yield compared to that of a synthetic carbohydrate type substrate [5]. Compared to the biological maximum potential, the reason for the lower hydrogen recovery is unclear. Hydrogen production can be affected by the substrate characteristics, operating conditions, some inhibition by chemicals, and homoacetogenesis reactions, etc. [3-5]. Four fermentation pathways have been widely accepted to occur in the anaerobic acidogenesis of organic matter, namely acetate-type, butyrate-type, ethanol-type and lactate-type fermentation (Table S1). The primary byproducts of acetate-type fermentation can be acetate and butyrate for butyrate-type fermentation, whereas propionate (with acetate and butyrate) can be produced by lactate-type fermentation. Ethanol and butyrate can be the main byproducts of ethanol-type fermentation. Based on the fermentation types, the major and minor products are summarized with microorganisms involved in each fermentation pathway (Table S2).

In fermentative hydrogen production, $\mathrm{pH}$ is an important factor that affects the hydrogenase activity and metabolism pathway [5]. In general, the optimal initial $\mathrm{pH}$ of fermentative hydrogen production is believed to be between 5.5 and 6.7 [2]. On the other hand, many studies on the initial $\mathrm{pH}$ effect in biohydrogen fermentation reported a slightly different conclusion. For example, in batch experiments using sucrose-rich synthetic wastewater, the initial $\mathrm{pH}$ (4.5-7.5) conditions did not show any significant effects on the hydrogen production rate [4]. In a series of batch tests using sucrose and starch, Khanal et al. [6] concluded that the initial $\mathrm{pH}$ had profound effects on both the hydrogen production potential and hydrogen production rate under an initial $\mathrm{pH}$ of 4.5-6.5.

Previous studies reported a significant increase in hydrogen production under alkaline $\mathrm{pH}$ conditions when sucrose or sewage sludge was used as the substrate. Lee et al. [7] reported that the optimal initial $\mathrm{pH}$ for the biohydrogen fermentation of sucrose was 9.0. Cai et al. [8] showed that the maximal hydrogen yield from sewage sludge occurred at an initial $\mathrm{pH}$ of 11.0. In an acid elutriation 
fermenter treating municipal primary sludge and slurry-type piggery waste, the maximal activity of hydrolysis and acidogenesis was $\mathrm{pH} 9$ under both mesophilic $\left(35^{\circ} \mathrm{C}\right)$ and thermophilic $\left(55^{\circ} \mathrm{C}\right)$ conditions [9,10]. Under these conditions, the main reaction byproducts in the semi-continuous experiments were acetate, propionate and butyrate, and the ratio was 1:0.35-0.37:0.28-0.31 for mesophilic conditions and 1:0.23-0.36:0.16-0.28 for thermophilic conditions. These results suggest that alkaline $\mathrm{pH}$ conditions have a broader application potential for biohydrogen fermentation and the acidogenesis of actual waste.

Alkalinity requirements for methanogenic reactors are well known, however, the requirements for biohydrogen production are not well established. Mohammadi et al. [11] studied the effect of bicarbonate concentration ranging from 0.2 to $2 \mathrm{~g} \mathrm{CaCO}_{3} / \mathrm{L}$ and achieved the maximum hydrogen yield at bicarbonate alkalinity (BA) of $1.1 \mathrm{~g} \mathrm{CaCO}_{3} / \mathrm{L}$. Valdez-Vazquez and Poggi-Varaldo [12] showed that biohydrogen production was influenced by alkalinity and total solids concentrations. Although the effect of alkalinity was previously studied, the detailed information regarding the effect of high alkalinity feed such as raw piggery waste is still scarce. The characteristics of biohydrogen production from piggery waste that contains high alkalinity $\left(\sim 9 \mathrm{~g} \mathrm{CaCO}_{3} / \mathrm{L}\right)$ were studied at the $\mathrm{pH}$ of 6 and 9 [13], however, the effect of high alkalinity was excluded.

In this study, the effects of the initial BA in biohydrogen fermentation were examined by performing a series of batch experiments with a sole organic substrate (sucrose for synthetic) and piggery waste (for actual waste). The optimal initial alkalinity conditions for improving biohydrogen production were estimated based on the specific hydrogen production rate and its effects on the intermediate products were also tested.

\section{Materials and Methods}

\subsection{Seed Sludge}

Anaerobic granular sludge, which was obtained from a full scale upflow anaerobic sludge bed (UASB) reactor treating brewery wastewater in Kwangju City, Korea, was used as the seed inocula. The hydrogen producing bacteria of the anaerobic sludge were screened by adopting heat treatment, which is the most common method $[5,13]$. The granular sludge was pretreated (baked) in an oven at $105{ }^{\circ} \mathrm{C}$ for $2 \mathrm{~h}$ and cooled to room temperature in a desiccator. The heat-treated sludge was homogenized by a blender before the experiment.

\subsection{Experimental Procedure}

This experiment was divided into three categories: (1) effect of the initial pH (Run I); (2) effect of the BA (Run II to V); and (3) using real waste with high $\mathrm{pH}$ and alkalinity. Therefore, the first experiment (Run I) was performed under several designated $\mathrm{pH}$ conditions without the supplementation of BA using a simple carbohydrate (sucrose) as the substrate. The initial $\mathrm{pH}$ ranged from 5 to 10 using $\mathrm{HCl}(1 \mathrm{M})$ and $\mathrm{NaOH}(1-2 \mathrm{M})$. For the second experiment (Run II to $\mathrm{V}$ ), $\mathrm{NaHCO}_{3}$ was added to the designated levels from zero to $13.1 \mathrm{~g} \mathrm{CaCO}_{3} / \mathrm{L}$ (or $17.5 \mathrm{~g} \mathrm{CaCO}_{3} / \mathrm{L}$ of total alkalinity) under the designated initial $\mathrm{pH}$ levels (from $\mathrm{pH} 5$ to 10). Table 1 summarizes the overall experimental conditions for the serum bottle activity test for batch mode biohydrogen fermentation. The serum 
bottles with a working volume of $100 \mathrm{~mL}$ (total reactor volume of $156 \mathrm{~mL}$ ) were used for the experiment. $30 \mathrm{~mL}(25 \mathrm{~g}$ ) of the heat-treated biomass (fraction of volatile suspended solids (VSS)/total suspended fraction $(\mathrm{TSS})=0.72$ ) was placed into each serum bottle. Run I was operated with $16 \mathrm{~g} / \mathrm{L}$ of the initial COD and $20 \mathrm{~mL} / \mathrm{L}$ of a salt stock solution. In Runs II to $\mathrm{V}, 4 \mathrm{~mL}$ of a concentrated organic substrate stock solution ( $255 \mathrm{~g} / \mathrm{L}$ of sucrose) and $66 \mathrm{~mL}$ of a diluted nutrient solution (contained with $20 \mathrm{~mL} / \mathrm{L}$ of salt stock solution) were added to the reactor. The organic substrate was not added to the control reactor. Each liter of salt stock solution contained $\mathrm{KH}_{2} \mathrm{PO}_{4} 13.61 \mathrm{~g} / \mathrm{L}, \mathrm{NH}_{4} \mathrm{Cl} 49.20 \mathrm{~g} / \mathrm{L}$, $\mathrm{CaCl}_{4} 4.44 \mathrm{~g} / \mathrm{L}, \mathrm{MgCl}_{2} \cdot 6 \mathrm{H}_{2} \mathrm{O} 8.13 \mathrm{~g} / \mathrm{L}$ and $10 \mathrm{~mL} / \mathrm{L}$ of a trace element solution containing $\mathrm{FeCl}_{3} 19.44 \mathrm{~g} / \mathrm{L}$, $\mathrm{MnCl}_{2} 4 \mathrm{H}_{2} \mathrm{O} 4.74 \mathrm{~g} / \mathrm{L}, \mathrm{ZnCl}_{2} 3.27 \mathrm{~g} / \mathrm{L}, \mathrm{CuCl}_{2} 2 \mathrm{H}_{2} \mathrm{O} 2.05 \mathrm{~g} / \mathrm{L}, \mathrm{CoCl}_{2} 6 \mathrm{H}_{2} \mathrm{O} 2.86 \mathrm{~g} / \mathrm{L}, \mathrm{Na}_{2} \mathrm{~B}_{4} \mathrm{O}_{7} 10 \mathrm{H}_{2} \mathrm{O}$ $1.15 \mathrm{~g} / \mathrm{L}, \mathrm{Na}_{3} \mathrm{C}_{6} \mathrm{H}_{5} \mathrm{O}_{7} 176.5 \mathrm{~g} / \mathrm{L},\left(\mathrm{NH}_{4}\right)_{6} \mathrm{Mo}_{6} \mathrm{O}_{24} 4 \mathrm{H}_{2} \mathrm{O} 2.08 \mathrm{~g} / \mathrm{L}$, and $\mathrm{NiCl}_{2} 6 \mathrm{H}_{2} \mathrm{O} 3.00 \mathrm{~g} / \mathrm{L}$.

Table 1. Operational conditions for serum bottle activity test.

\begin{tabular}{cccccccc}
\hline \multirow{2}{*}{ Run } & Bicarbonate & \multicolumn{5}{c}{ Initial Bicarbonate Alkalinity (mg CaCO $/ \mathbf{L})$} \\
\cline { 3 - 8 } & Alkalinity Control & $\mathbf{p H ~ 5}$ & $\mathbf{p H ~ 6}$ & $\mathbf{p H ~ 7}$ & $\mathbf{p H ~ 8}$ & $\mathbf{p H ~ 9}$ & $\mathbf{p H ~ 1 0}$ \\
\hline I & No & 0 & 13 & 79 & 214 & 379 & 663 \\
II & Yes & 0 & 21 & 113 & 221 & 506 & 1,023 \\
III & Yes & 0 & 450 & 2,525 & 3,038 & 3,175 & 4,663 \\
IV & Yes & 0 & 978 & 3,129 & 4,201 & 4,488 & 6,551 \\
V & Yes & 0 & 575 & 5,050 & 6,113 & 6,363 & 13,100 \\
\hline
\end{tabular}

Notes: pHs were amended with $\mathrm{HCl}$ and $\mathrm{NaOH}$ for run $\mathrm{I}$, and $\mathrm{HCl}$ and $\mathrm{NaHCO}_{3}$ for run II-V. The amount of BA varied $\left(\sim 320,3,200,4,200\right.$ and $6,500 \mathrm{mg} \mathrm{CaCO}_{3} / \mathrm{L}$ for phase II-V, respectively) before making the designated pHs. Sucrose was used for a substrate.

For the third experiment examining real waste, raw piggery waste was obtained from the inlet of a livestock waste treatment plant (Sangju, Korea) and stored in a temperature-controlled room $\left(4{ }^{\circ} \mathrm{C}\right)$. The characteristics of the piggery waste were as follows: $35 \mathrm{~g} \mathrm{COD} / \mathrm{L}, 24.4 \mathrm{~g} / \mathrm{L}$ of total solids (TS), $0.63 \%$ volatile solids fraction (VS/TS), $\mathrm{pH} 8.7$ and $9.0 \mathrm{~g} \mathrm{CaCO}_{3} / \mathrm{L}$ of BA (12 $\mathrm{g}$ of total alkalinity, TA). The serum bottle reactors were operated with $90 \mathrm{~mL}$ of the pre-treated (screened for coarse particle) slurry-type piggery waste and $10 \mathrm{~mL}$ of the homogenized anaerobic granular sludge $(10 \mathrm{~mL})$ pretreated with heat $\left(104^{\circ} \mathrm{C}\right.$ for $\left.2 \mathrm{~h}\right)$.

The serum bottles were capped with a Wheaton rubber septum stopper and flushed with oxygen-free $\mathrm{N}_{2}$ gas $(99.99 \%$ ) for $30 \mathrm{~s}$ to remove the oxygen from the solution. The bottles were operated in an orbital shaker (SI-600R, Lab Companion, Daejeon, Korea) running at $200 \mathrm{rpm}$ in a temperature-controlled room $\left(35 \pm 1{ }^{\circ} \mathrm{C}\right)$. Each experiment was triplicated and operated with three cycles under constant operating conditions. Control bottles (blank) were also operated without a substrate. The biogas produced was measured using the displacement method with appropriately sized wetted glass syringes. All experiments were performed according to the biochemical methane potential (BMP) protocol [14,15]. The mean values from batch experiments were used for plotting graphs.

\subsection{Analysis}

The hydrogen gas fraction (percentage of $\mathrm{H}_{2}$ and $\mathrm{CO}_{2}$ ) in the headspace of the serum bottle was determined using a $500 \mu \mathrm{L}$ gastight syringe, and the collected biogas was compared with a standard of 
pure $\mathrm{H}_{2}(99.99 \%)$ using a gas chromatograph (GC, Shimadzu GC-14B, Kyoto, Japan) equipped with a thermal conductivity detector (TCD). The column was $6 \mathrm{ft} \times 1 / 8$ in stainless steel (SS) 350A Molecular Sieve $13 \times 80 / 100$ (Alltech, State College, PA, USA). The operational temperatures of the injection port, oven and detector were 100,50 and $100{ }^{\circ} \mathrm{C}$, respectively. $\mathrm{N}_{2}$ was used as the carrier gas at a flow rate of $75 \mathrm{~mL} / \mathrm{min}$. The minimum amount of $\mathrm{H}_{2}$ detectable was $1 \%$.

$\mathrm{N}_{2}, \mathrm{CO}_{2}$ and $\mathrm{CH}_{4}$ were determined by comparing the collected biogas with a standard of pure (99.99\%) $\mathrm{N}_{2}, \mathrm{CO}_{2}$, and $\mathrm{CH}_{4}$ using a gas chromatograph (Shimadzu GC-8A) with a $6 \mathrm{ft} \times 1 / 8$ in SS Hayasep Q 80/100 column (Alltech). The column temperature program was ramped to $200{ }^{\circ} \mathrm{C}$ at $10{ }^{\circ} \mathrm{C} / \mathrm{min}$. The injector and detector temperatures were $120^{\circ} \mathrm{C}$. Helium was used as the carrier gas with a flow rate of $140 \mathrm{~mL} / \mathrm{min}$. The minimum detectable amount of $\mathrm{CH}_{4}$ was $1 \%$.

The concentrations of volatile organic acids, such as lactate, acetate, propionate, and butyrate, were analyzed using filtrate samples through a $0.45 \mu \mathrm{m}$ membrane by high performance liquid chromatography (HPLC, Shimadzu) equipped with an auto-injector, under isocratic elution conditions with UV-Vis detection (Shimadzu SPD-10A) at $210 \mathrm{~nm}$ and an Aminex HPX-87H column $(300 \mathrm{~mm} \times 7.8 \mathrm{~mm}$, Bio-Rad, Hercules, CA, USA). The flow rate and pressure of the HPLC pump were $0.6 \mathrm{~mL} / \mathrm{min}$ and $88-89 \mathrm{kgf} / \mathrm{cm}^{2}$, respectively. The column oven temperature was $35{ }^{\circ} \mathrm{C}$, and $0.008 \mathrm{M} \mathrm{H}_{2} \mathrm{SO}_{4}$ used as the eluent. The $\mathrm{pH}$ was measured using a $\mathrm{pH}$ meter (Orion 470, Waltham, MA, USA). The chemical oxygen demand (COD) was measured using a colorimetric method according to Standard Methods [16]. The BA and TA were analyzed using the Kappe methods [17].

The accumulated volume of the hydrogen production potential over time during the tests was fitted with the modified Gompertz equation [18,19]:

$$
H=P \exp \left\{-\exp \left[\frac{R_{m} e}{P}(\lambda-t)+1\right]\right\}
$$

where $H$ is the cumulative hydrogen production $(\mathrm{mL}), P$ is the hydrogen production potential $(\mathrm{mL})$, $\lambda$ is the lag phase time $(\mathrm{h}), R_{m}$ is the maximum hydrogen production rate $(\mathrm{mL} / \mathrm{h}), t$ is the incubation time $(\mathrm{h})$, and $e$ is the $\exp (1)=2.718$. The parameters were estimated using the solver function in Microsoft Excel version 5.0 (Microsoft, Inc., New York, NY, USA). Subsequently, contour plots were constructed using the SigmaPlot Ver. 10 software (Systat Software Inc., San Jose, CA, USA) to show the effect of BA and $\mathrm{pH}$ on biohydrogen production.

\section{Results and Discussion}

\subsection{Hydrogen Yield under Various pHs Condition}

In the first step of the experiment excluding the effects of BA in the substrate, most reactors designed for a range of initial $\mathrm{pH}$ levels required approximately 5-6 $\mathrm{h}$ of lag time for hydrogen production except for those at $\mathrm{pH} 9$ and 10 (approximately $8-15 \mathrm{~h}$ of lag time). Figure la presents the hydrogen yield, showing that there was no significant difference in the hydrogen yield ( $0.12 \mathrm{~g} \mathrm{COD} \mathrm{H}_{2} / \mathrm{g} \mathrm{COD}, 268-272 \mathrm{~mL} \mathrm{H}_{2} / \mathrm{g}$ hexose) at the initial $\mathrm{pH}$ from 5 to 7 . The fraction of hydrogen was in a range of between $80.2 \%$ and $84.1 \%$ under $\mathrm{pH} 5-8$ and $92.1 \%$ at $\mathrm{pH} 9$ conditions. Hydrogen production was possible in a range of $\mathrm{pH} 5$ to 9 . The finding suggests that various organic wastes covering a wide range of $\mathrm{pH}$ values can be used for hydrogen fermentation without adjusting the 
initial $\mathrm{pH}$. Lee et al. [7] reported that hydrogen production yields were higher at high alkaline $\mathrm{pH}$ than lower $\mathrm{pH}$ conditions ( $\mathrm{pH}$ from 5 to 8 ), suggesting that hydrogenase enzyme systems are functioned at high alkaline $\mathrm{pH}$ conditions. Hydrogen production yield in the initial $\mathrm{pH} 10$ decreased with a long lag time, which could be due to the toxic effects of a high $\mathrm{pH}$. When $\mathrm{pH}$ condition increases from 9 to 10 , the distribution of bicarbonate and carbonate is switched in the system, leading to the reduction of bicarbonate (Figure S1). Accordingly, high $\mathrm{pH}$ condition caused the decrease of $\mathrm{H}_{2}$ production yield, suggesting the inhibition of growth rate and metabolic activity of bacteria [20].
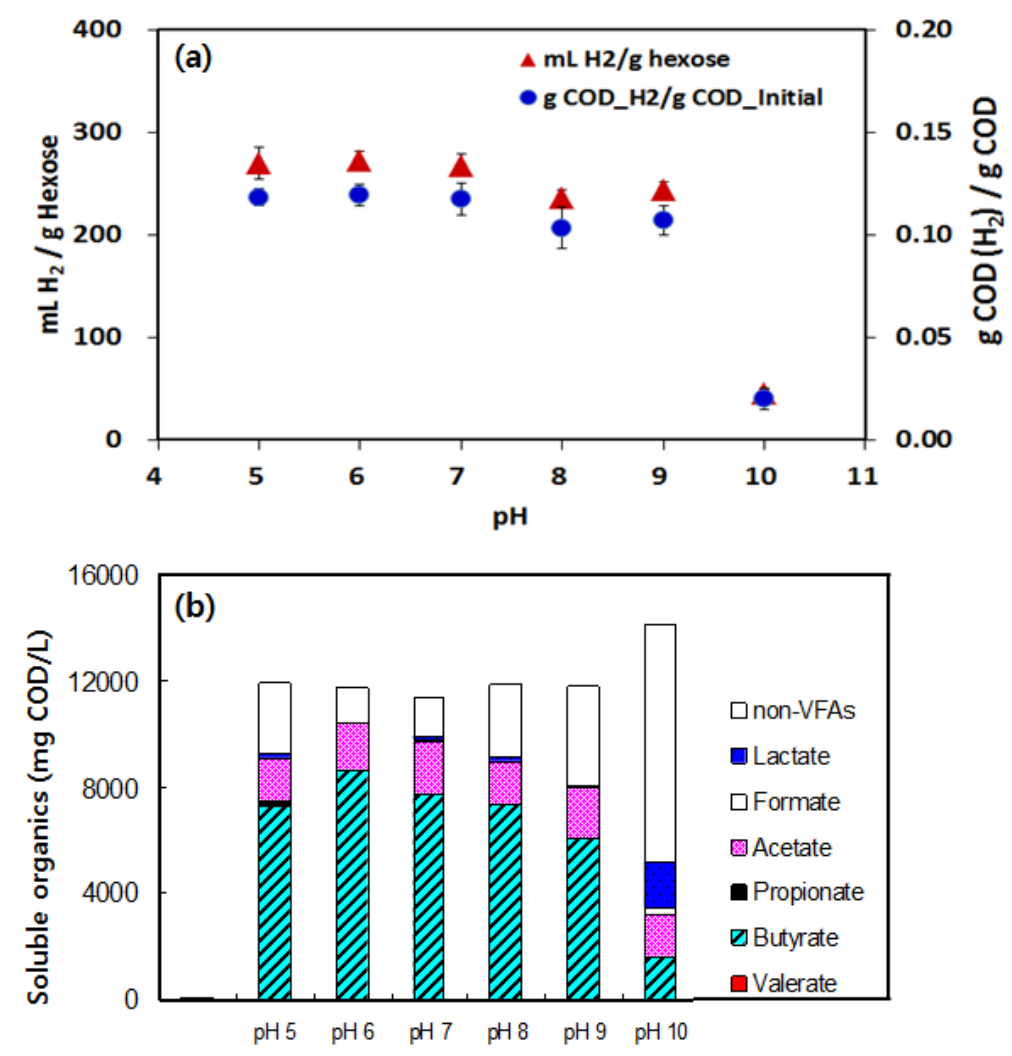

Figure 1. Hydrogen yield (a) and organic acids production (b) under designated pHs without BA supplementation (substrate: sucrose, initial COD $=16 \mathrm{~g} / \mathrm{L}$ ).

Figure $1 \mathrm{~b}$ represents the profile of soluble organics produced in hydrogen fermentation under a range of pHs. At $\mathrm{pH} 5$ to 9, butyrate was the most dominant byproduct, followed by acetate, whereas relatively lower butyrate and higher lactate concentrations were observed at $\mathrm{pH} 10$. The distribution of a byproduct in hydrogen fermentation provides an important indication that the butyrate/acetate ratio can be the indicator evaluating the effectiveness of hydrogen production [21]. At an initial pH 5 to 9 , the butyrate and acetate concentrations were 6.02-8.51 g COD/L and 1.51-2.23 g COD/L, respectively. The butyrate/acetate ratios were $3.5-5.0$ at $\mathrm{pH} 5$ to 9 , and 1.06 at $\mathrm{pH} 10$. These ratios were comparable to the previous data (3.7-5.1) obtained in a hydrogen fermenter fed with sucrose [22]. A greater than 2.6 of butyrate/acetate ratio also showed efficient hydrogen production from a wheat starch co-product by anaerobic microflora [23]. Therefore, a high hydrogen yield is typically associated with the production of butyrate, and low yields with propionate production and reduced products (e.g., lactate or alcohol). This is correspondent to the increase in lactate and the decrease in butyrate in the $\mathrm{pH} 10$ reactor. 
The pHs $(7,8,9)$ in reactors were dropped immediately except at $\mathrm{pH} 10$ when hydrogen fermenter was started (Figure 2). A drop of $\mathrm{pH}$ in the reactors is possibly due to volatile fatty acid (VFA) accumulation and weak buffering capacity. From the initial $\mathrm{pH} 10$ test, the $\mathrm{pH}$ was slightly reduced from 10 to 9.1 during the initial $12 \mathrm{~h}$ possibly due to the low acidogenesis, compared to other $\mathrm{pH}$ conditions. Regardless of what the initial $\mathrm{pH}$ was (4-9) in the experiments, the $\mathrm{pH}$ changed with time, and the final $\mathrm{pH}$ was between 4.5 and 5.9.

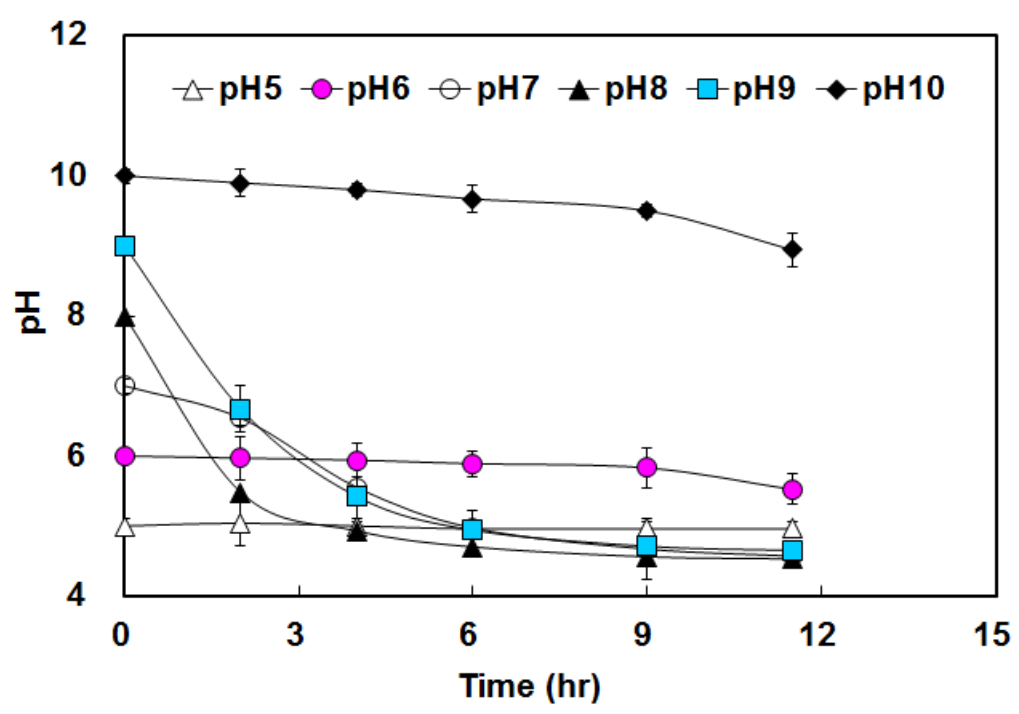

Figure 2. $\mathrm{pH}$ profiles during the batch biohydrogen fermentation (substrate: sucrose). Bicarbonate alkalinity was not amended.

\subsection{Effects of $B A$}

BA has buffering capacity to reduce the large $\mathrm{pH}$ fluctuations during hydrogen fermentation accompanied by VFA or solvents. A failure of $\mathrm{pH}$ control from alkalinity and the imbalance between the organic acids may result in interfering hydrogen production. Furthermore, bicarbonate correlates with $\mathrm{pH}$ and carbon dioxide, which is the other end product in anaerobic fermentation [15]. High BA in the feed can increase the $\mathrm{CO}_{2}$ fraction in the reactor, suggesting the possibility of hydrogen consumption (i.e., acetate production) by homoacetogenesis [21]. Zhang and Wang [20] reported that suitable addition of alkali-rich materials to food waste synergistically improved hydrogen fermentation performance and lag time, which attributed to buffering effect and nutrient characteristics of hydrogen metabolism.

The initial BA and pH significantly affected the hydrogen yield, as shown in Table 2 and Figure 3. When low alkalinity $\left(<0.1 \mathrm{~g} \mathrm{CaCO}_{3} / \mathrm{L}\right)$ was present, the maximum hydrogen yield was $\sim 1.5 \mathrm{~mol} \mathrm{H} / \mathrm{mol}$ glucose at $\mathrm{pH} 6$ and 7, whereas $\sim 1.08 \mathrm{~mol} \mathrm{H}_{2} / \mathrm{mol}$ glucose in $\mathrm{pH} 8$ and 9 conditions, where the initial BA of $\sim 2.5 \mathrm{~g} \mathrm{CaCO}_{3} / \mathrm{L}$ were present. When the initial BA increased to more than $3 \mathrm{~g} \mathrm{CaCO}_{3} / \mathrm{L}$,

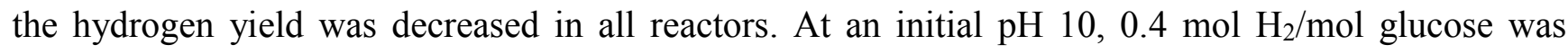
produced in low BA, whereas no hydrogen production was observed in high $\mathrm{BA}\left(>7 \mathrm{~g} \mathrm{CaCO}_{3} / \mathrm{L}\right)$. Despite the buffering capacity of BA, higher concentration of BA could be a cause of toxicity in the fermentation process. Moreover, excess addition of alkali-rich materials may be harmful to hydrogen-producing microbes and reduce $\mathrm{H}_{2}$ production from food waste [20]. Figure 4 shows a 
hydrogen production rate at the initial $\mathrm{BA}$ doses and $\mathrm{pH}$. The specific hydrogen production rates were 0.26 and $0.29 \mathrm{~L} \mathrm{H}_{2} / \mathrm{g}$ VSS-d at an initial $\mathrm{pH}$ of 7 and 8 (with initial $\mathrm{BA}$ dose of 2.5 and $3.0 \mathrm{~g} \mathrm{CaCO}_{3}$, respectively), and the highest hydrogen production rate of $0.32 \mathrm{~L} \mathrm{H}_{2} / \mathrm{g}$ VSS-d was observed at $\mathrm{pH} 8.95$ with an initial BA of $3.18 \mathrm{~g} \mathrm{CaCO}_{3} / \mathrm{L}$. Zhu et al. [24] reported that the addition $1.0 \mathrm{M} \mathrm{K}_{2} \mathrm{HPO}_{4}$ could increase hydrogen production, whereas less hydrogen production was confirmed under high buffer addition. Based on these results, the initial BA in the substrates can significantly affect hydrogen production, indicating a strong effect on major metabolites of $\mathrm{H}_{2}$-producing bacteria. $\mathrm{BA}$ greater than $4 \mathrm{~g} \mathrm{CaCO}_{3} / \mathrm{L}$ led to a decrease in the specific hydrogen production rates $\left(<0.13 \mathrm{~L} \mathrm{H}_{2} / \mathrm{g} \mathrm{VSS}-\mathrm{d}\right)$. The performance of hydrogen fermenter can be affected by level of TA and BA $[11,13,21]$.

Table 2. Specific hydrogen production rate in various $\mathrm{pHs}$ and BA level.

\begin{tabular}{|c|c|c|c|c|c|}
\hline Run & pH & $\begin{array}{l}\text { Bicarbonate Alkalinity } \\
\left(\mathrm{mg} \mathrm{CaCO}_{3} / \mathrm{L}\right)\end{array}$ & $\begin{array}{c}\mathrm{H}_{2} \text { Yield } \\
\left(\mathrm{mol} \mathrm{H}_{2} / \mathrm{mol} \text { glucose }\right) \\
\end{array}$ & 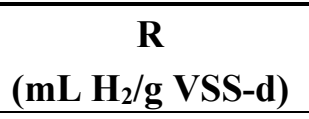 & $r / r_{\max }$ \\
\hline \multirow{6}{*}{ II } & 4.95 & 0 & 1.38 & 63.9 & 0.2 \\
\hline & 6.00 & 21 & 1.51 & 71.8 & 0.23 \\
\hline & 7.04 & 113 & 1.60 & 62.9 & 0.20 \\
\hline & 8.05 & 221 & 1.28 & 49.3 & 0.15 \\
\hline & 9.07 & 379 & 0.82 & 49.1 & 0.15 \\
\hline & 9.98 & 663 & 0.43 & 18.1 & 0.06 \\
\hline \multirow{6}{*}{ III } & 5.00 & 0 & 1.15 & 139.1 & 0.44 \\
\hline & 6.10 & 450 & 1.23 & 154.9 & 0.49 \\
\hline & 7.10 & 2,525 & 1.36 & 258.3 & 0.81 \\
\hline & 8.10 & 3,038 & 1.46 & 296.4 & 0.93 \\
\hline & 8.95 & 3,175 & 1.48 & 318.5 & 1.00 \\
\hline & 10.10 & 4,663 & 0.01 & 15.6 & 0.05 \\
\hline \multirow{6}{*}{ IV } & 5.02 & 0 & 0.52 & 56.6 & 0.18 \\
\hline & 6.17 & 978 & 1.01 & 109.6 & 0.34 \\
\hline & 7.13 & 3,129 & 1.00 & 143.9 & 0.45 \\
\hline & 8.12 & 4,201 & 1.00 & 133.8 & 0.42 \\
\hline & 9.01 & 4,488 & 1.02 & 121.5 & 0.38 \\
\hline & 9.96 & 6,551 & 0.12 & 11.0 & 0.03 \\
\hline \multirow{6}{*}{$\mathrm{V}$} & 5.14 & 0 & 0.52 & 40.3 & 0.13 \\
\hline & 6.27 & 575 & 0.88 & 65.4 & 0.21 \\
\hline & 7.36 & 5,050 & 0.76 & 81.9 & 0.26 \\
\hline & 8.10 & 6,113 & 0.85 & 101.6 & 0.32 \\
\hline & 8.99 & 6,363 & 0.40 & 61.8 & 0.19 \\
\hline & 10.10 & 13,100 & 0.00 & 0.00 & 0.00 \\
\hline
\end{tabular}

Note: " $r$ " and " $r / r_{\max }$ " represent $\mathrm{H}_{2}$ production activity and normalized activity by maximum $\mathrm{H}_{2}$ production activity, respectively. 


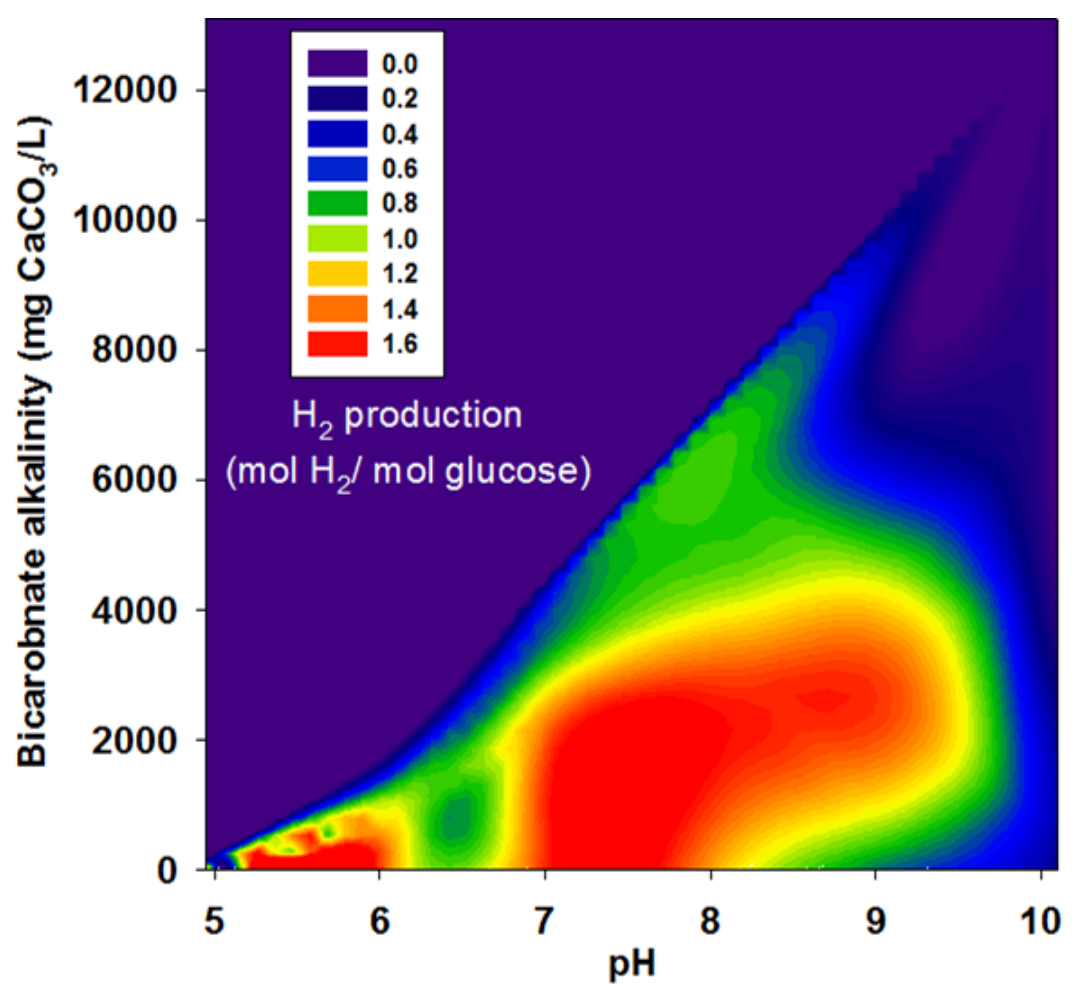

Figure 3. Hydrogen yield (mol $\mathrm{H}_{2} / \mathrm{mol}$ glucose) with variation of BA and $\mathrm{pHs}$ (substrate: sucrose).

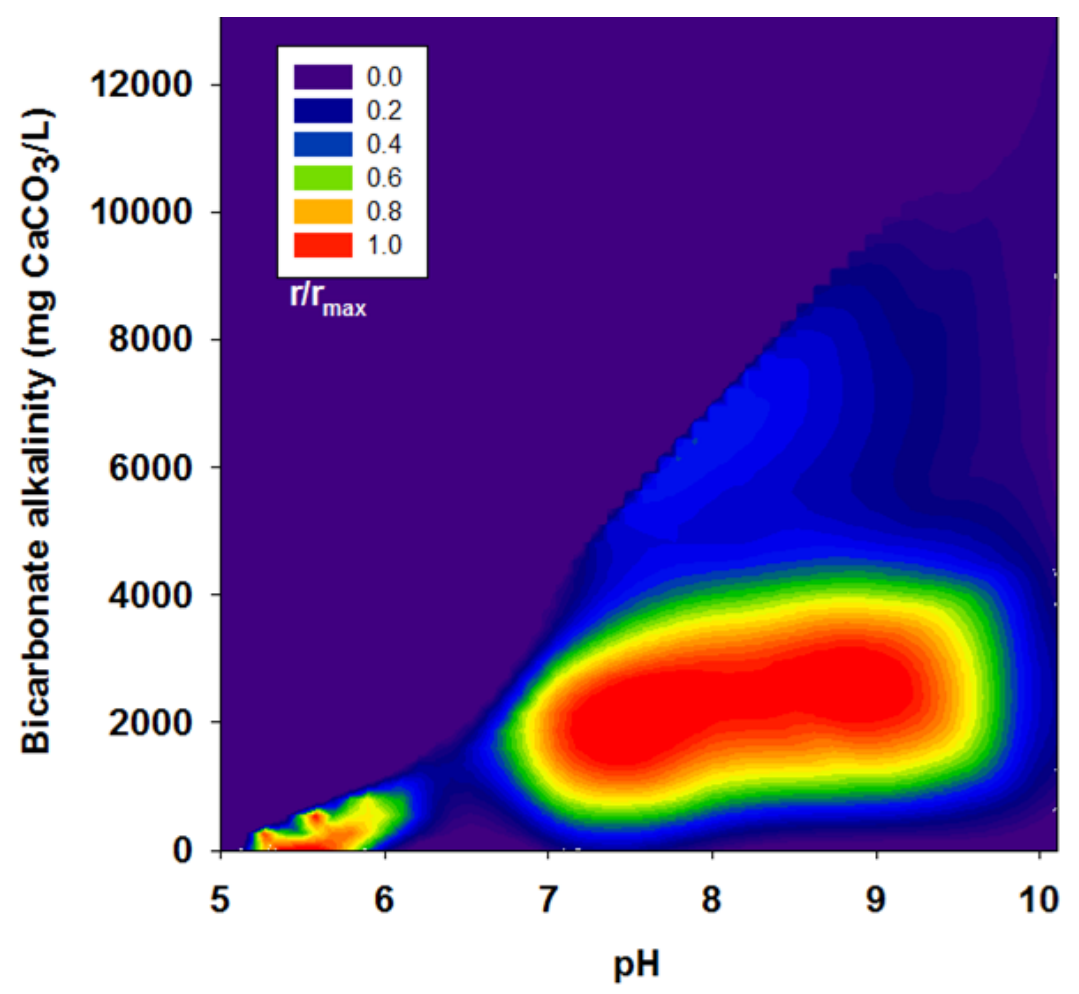

Figure 4. Hydrogen production rate of $\mathrm{H}_{2}$ producing mixed culture with BA (substrate: sucrose). The $r / r_{\max }$ represents that specific hydrogen production rate ( $\mathrm{mL} \mathrm{H}_{2} / \mathrm{g}$ VSS-d) is divided by maximum hydrogen production activity.

Even though the level of alkalinity range was relatively high, critical hydrogen production at high alkalinity ranges was observed in this and previous studies [7] and effect of high alkalinity was required to 
apply with a real waste including high alkalinity itself, such as piggery waste (alkalinity $=8.9 \mathrm{~g} \mathrm{CaCO}_{3} / \mathrm{L}$, $\mathrm{pH}$ 8.7) [13].

\subsection{Acetate and Butyrate as the Final Byproducts}

Each type of hydrogen fermentation could be characterized by hydrogen producing and consuming thermodynamical reaction under different $\mathrm{pH}$ and microbial properties, determining the main byproducts (Table S1). One of the widely studied hydrogen-producing microorganisms is Clostridium butyricum, which produces butyric acids as the major byproduct with $\mathrm{CO}_{2}$, acetic acid and $\mathrm{H}_{2}$. This pathway was found in approximately 50\% of experimental studies that isolated Clostridia to date [6]. Other fermentation pathways include the production of propionate by Clostridium arcticum [25], succinate by Clostridium coccides [26] and lactate by Clostridium barkeri [27].

Figure $5 \mathrm{a}$ shows the ratios of acetate and butyrate in the total organic acids. When the bicarbonate concentration was higher than $4 \mathrm{~g} \mathrm{CaCO}_{3} / \mathrm{L}$, butyrate was reduced significantly, meaning that butyrate type fermentation was reduced, whereas the acetate concentration was increased. The increase in acetate by acetate type fermentation could be due to the decrease in hydrogen production up to $4 \mathrm{~g} \mathrm{CaCO}_{3} / \mathrm{L}$ (Figures 3 and 4). On the other hand, when the bicarbonate concentration was sufficient in the liquid phase, the hydrogen produced can be consumed by homoacetogenesis, resulting in the acetate production (see the Equations (3) and (4)). Lin and Lay [21] reported that a high $\mathrm{NH}_{4} \mathrm{HCO}_{3}$ concentration resulted in low hydrogen production due to bicarbonate dissolution and the toxicity of a high ammonium concentration:

$$
\begin{gathered}
2 \mathrm{HCO}_{3}{ }^{-}+4 \mathrm{H}_{2}+\mathrm{H}^{+} \rightarrow \text { acetate }^{-}+4 \mathrm{H}_{2} \mathrm{O}, \Delta \mathrm{G}^{\prime}(\mathrm{kJ} / \mathrm{mol})=-104.5 \\
4 \mathrm{H}_{2}+\mathrm{CO}_{2} \rightarrow \text { acetate }^{-}+\mathrm{H}^{+}+4 \mathrm{H}_{2} \mathrm{O}, \Delta \mathrm{G}^{\prime}(\mathrm{kJ} / \mathrm{mol})=-94.9
\end{gathered}
$$

\subsection{Lactate and Propionate as Final Byproducts}

In general, propionate is not a major byproduct of the fermentative biohydrogen production process. According to thermodynamically potential pathway of hydrogen fermentation, propionate production can be observed only in the pathway of lactate-type fermentation, resulting in the consumption of the hydrogen produced (Table S1). Therefore, propionate accumulation in the reactor can also be a barrier for hydrogen and lactate production [2].

Figure $5 \mathrm{~b}$ shows the effects of $\mathrm{BA}\left(0-1.31 \mathrm{~g} \mathrm{CaCO}_{3} / \mathrm{L}\right)$ in the ratio of the acids per total organic acids. Almost no relationship was observed between BA and the acid/total organic acids ratios under $4 \mathrm{~g} \mathrm{CaCO}_{3} / \mathrm{L}$. On the other hand, the lactate ratio increased to $0.16 \mathrm{~g} / \mathrm{g}$ at $6 \mathrm{~g} \mathrm{CaCO}_{3} / \mathrm{L}$ and the propionate ratio reached $0.16 \mathrm{~g} / \mathrm{g}$ at $6.5 \mathrm{~g} \mathrm{CaCO}_{3} / \mathrm{L}$. With further increases in $\mathrm{BA}$ from $6.5 \mathrm{~g} \mathrm{CaCO}_{3} / \mathrm{L}$, the propionate ratio increased and the lactate ratio decreased, possibly due to lactate-type fermentation, which involves the accumulation of propionate as a byproduct. 

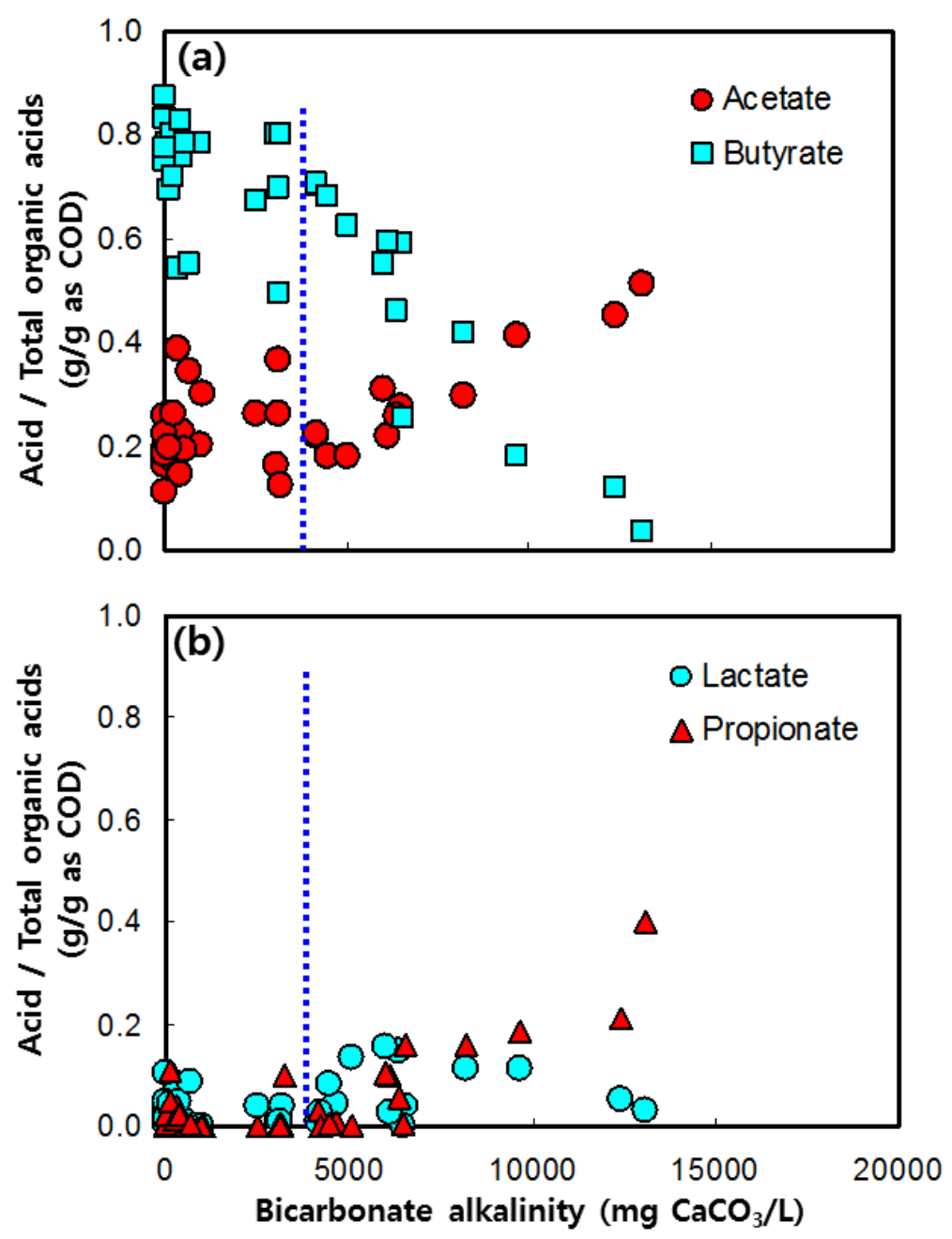

Figure 5. (a) Acetate and butyrate, (b) lactate and propionate in the batch hydrogen fermentation (substrate: sucrose) as a function of the BA.

\subsection{BA in High Strength Piggery Waste}

BA is produced in fermentative hydrogen production processes and contributes to maintain the $\mathrm{pH}$ at favorable range for hydrogen producing activity. Limited studies, however, were performed on the effect of BA (Lin and Lay [21]; Mohammadi et al. [11]). In addition, a few results showing successful biohydrogen fermentation using real waste have been reported, and the hydrogen yield was much lower than with the pure feed [5]. In particular, biohydrogen fermentation from high strength piggery waste showed low energy recovery $[13,28,29]$, even though piggery waste is considered as an attractive source for bioenergy harvesting [9].

Figure 6 shows the batch mode experimental results of the effect of high BA using raw piggery waste (8.9 $\mathrm{g} \mathrm{CaCO}_{3} / \mathrm{L}, \mathrm{pH} 8.7$ ). No butyrate and biogas (hydrogen and methane) production was observed, whereas the acetate and propionate levels increased with time, indicating that the accumulation of acetate seems to imply the inhibition of acetate-consuming activity. On the other hand, the presence of homoacetogenic activity, that hydrogen and carbon dioxide are utilized, is possible due to the characteristics of raw piggery waste containing a high percentage of complex organic and inorganic molecules. The high BA is likely to affect the production of biohydrogen and organic acids by the consumption of BA and hydrogen produced. This can be explained by the distribution of the 
bicarbonate fractions, as previously described (Figure S1). Compared to the different $\mathrm{pH}$ condition

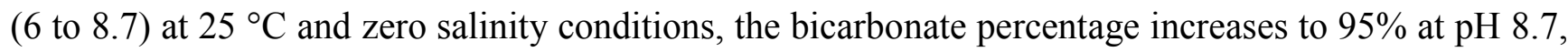
driving to more acetate production in the fermenter, potentially by activating homoacetogenesis. Therefore, the activity of the acetogenic bacteria can be favorable at high BA. Regarding the reaction converting hydrogen to acetate under anaerobic conditions (Equations (3) and (4)), the presence of acetogenic bacteria has been proposed to be responsible for the consumption of hydrogen produced during biohydrogen fermentation from organic wastewater or waste in the case of no methanogens [30]. This result showed that a proper amendment of the substrate characteristics (in levels of $\mathrm{pH}$ and bicarbonate contents) will be required for successful biohydrogen harvesting from organic waste with $\mathrm{pH}$ and $\mathrm{BA}$.

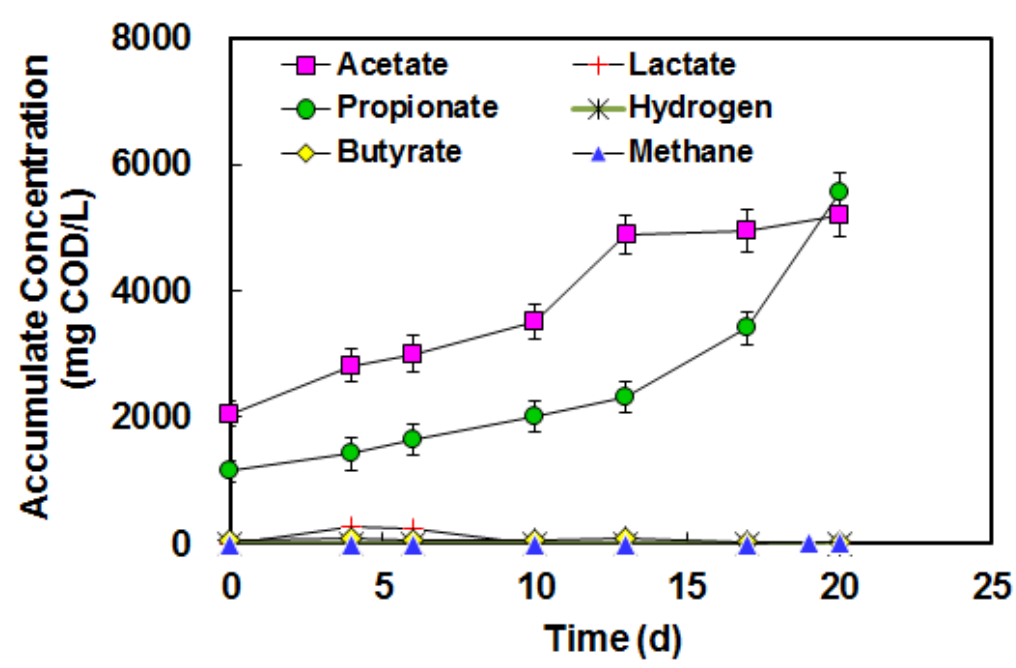

Figure 6. Profiles of organic acids and biogas in a batch mode fermenter using raw piggery waste and $\mathrm{H}_{2}$ producing mixed culture (BA: 8.9 $\mathrm{CaCO}_{3} / \mathrm{L}, \mathrm{pH} 8.7$ ).

\section{Conclusions}

The initial $\mathrm{BA}$ and $\mathrm{pH}$ of the feed substrates are very important parameters for fermentative biohydrogen production. Hydrogen production was observed over a wide range of $\mathrm{pH}$ values from 5 to 9 under the exclusion of alkalinity. The maximum hydrogen production rates were obtained at $\mathrm{pH}$ $9>8>7$ with $\sim 3 \mathrm{~g} \mathrm{CaCO}_{3} / \mathrm{L}$ of $\mathrm{BA}$. The significant decrease in hydrogen production over $\mathrm{BA}$ of $\sim 3 \mathrm{~g} \mathrm{CaCO}_{3} / \mathrm{L}$ was attributed to the effect of bicarbonate, which could be used as a carbon source for hydrogen consumers. The higher BA in the substrate resulted in higher acetate production, in which homoacetogens may be activated. Therefore these results demonstrate that the substrate with high BA should be amended to maximize hydrogen production adequately.

\section{Supplementary Materials}

Supplementary materials can be accessed at: http:/www.mdpi.com/1996-1073/8/3/1716/s1.

\section{Acknowledgments}

This work was supported by the 2014 Yeungnam University Research Grant. 


\section{Author Contributions}

Jeongdong Choi carried out the experiments and prepared the first draft, and Youngho Ahn managed this study and analyzed data deeply. Both authors contributed to the interpretation of the results.

\section{Conflicts of Interest}

The authors declare no conflict of interest.

\section{References}

1. A Multiyear Plan for the Hydrogen R \& D Program, Rationale, Structure and Technology Roadmaps; U.S. Department of Energy, Energy Efficiency and Renewable Energy, Office of Power Delivery, Office of Power Technologies: Washington, DC, USA, 1999.

2. Hawkes, F.R.; Dinsdale, R.; Hawkes, D.L.; Hussy, I. Sustainable fermentative hydrogen production: Challenges for process optimization. Int. J. Hydrog. Energy 2002, 27, 1339-1347.

3. Thauer, R.K.; Jungermann, K.; Decker, K. Energy conservation in chemotrophic anaerobic bacteria. Bacteriol. Rev. 1977, 41, 100-180.

4. Van Ginkel, S.; Sung, S.; Lay, J.J. Biohydrogen production as a function of $\mathrm{pH}$ and substrate concentration. Environ. Sci. Technol. 2001, 35, 4726-4730.

5. Li, C.; Fang, H.H.P. Fermentative hydrogen production from wastewater and solid wastes by mixed cultures. Crit. Rev. Environ. Sci. Technol. 2007, 37, 1-39.

6. Khanal, S.K.; Chen, W.H.; Li, L.; Sung, S. Biological hydrogen production: Effect of pH and intermediate products. Int. J. Hydrog. Energy 2004, 29, 1123-1131.

7. Lee, Y.; Miyahara, T.; Noike, T. Effect of $\mathrm{pH}$ on microbial hydrogen fermentation. J. Chem. Technol. Biotechnol. 2002, 77, 694-698.

8. Cai, M.; Liu, J.; Wei, Y. Enhanced biohydrogen production from sewage with alkaline pretreatment. Environ. Sci. Technol. 2004, 38, 3195-3202.

9. Ahn, Y.H.; Bae, J.; Park, S.; Min, K. Anaerobic digestion elutriated phased treatment of piggery waste. Water Sci. Technol. 2004, 49, 181-189.

10. Ahn, Y.H.; Speece, R.E. Elutriated acid fermentation of municipal primary sludge. Water Res. 2006, 40, 2210-2220.

11. Mohammadi, P.; Ibrahim, S.; Mohamad Annuar, M.S. Effects of biomass, COD and bicarbonate concentrations on fermentative hydrogen production from POME by granulated sludge in a batch culture. Int. J. Hydrog. Energy 2012, 37, 17801-17808.

12. Valdez-Vazquez, I.; Poggi-Varaldo, H.M. Alkalinity and high total solids affecting $\mathrm{H}_{2}$ production from organic solid waste by anaerobic consortia. Int. J. Hydrog. Energy 2009, 34, 3639-3646.

13. Choi, J.; Ahn. Y. Characteristics of biohydrogen fermentation from various substrates. Int. J. Hydrog. Energy 2014, 39, 3152-3159.

14. Owen, W.F.; Stuckey, D.D.; Healy, J.B., Jr.; Young, L.Y.; McCarty, P.L. Bioassay for monitoring biochemical methane potential and anaerobic toxicity. Water Res. 1979, 13, 485-493.

15. Speece, R.E. Anaerobic Biotechnology for Industrial Wastewaters; Archae Press: Nashville, TN, USA, 1996. 
16. Standard Methods for the Examination of Water and Wastewater, 20th ed.; the American Public Health Association, the American Water Works Association and the Water Environment Federation: Washington, DC, USA, 1998.

17. Buchauer, K. A comparison of two simple titration procedures to determine volatile fatty acids in influents to wastewater and sludge treatment processes. Water SA 1998, 24, 49-56.

18. Lay, J.J.; Lee, Y.J.; Noike, T. Feasibility of biological hydrogen production from organic fraction of municipal solids waste. Water Res. 1999, 33, 2576-2586.

19. Zwietering, M.H.; Jongenburger, I.; Rombouts, F.M.; Van's Riet, K. Modeling of the bacterial growth curve. Appl. Environ. Microbiol. 1990, 56, 1875-1881.

20. Zhang, J.; Wang, Q. Buffering and nutrient effects of white mud from ammonia-soda process on thermophilic hydrogen fermentation from food waste. Int. J. Hydrog. Energy 2013, 38, 13564-13571.

21. Lin, C.Y.; Lay, C.H. Effects of carbonate and phosphate concentrations on hydrogen production using anaerobic sewage sludge microflora. Int. J. Hydrog. Energy 2004, 29, 275-281.

22. Chen, C.C.; Lin, C.Y.; Lin, M.C. Acid-base enrichment enhances on anaerobic hydrogen production process. Appl. Microbiol. Biotechnol. 2002, 57, 224-228.

23. Hussy, I.; Hawkes, F.R.; Dinsdale, R.; Hawkes, D.L. Continuous fermentative hydrogen production from a wheat starch co-product by mixed microflora. Biotechnol. Bioeng. 2003, 84, 619-626.

24. Zhu, H.; Parker, W.; Basnar, R.; Proracki, A.; Falletta, P.; Beland, M.; Seto, P. Biohydrogen production by anaerobic co-digestion of municipal food waste and sewage sludges. Int. J. Hydrog. Energy 2008, 33, 3561-3659.

25. Jones, D.T.; Woods, D.R. Solvent production. In Biotechnology Handbooks, Vol.3, Clostridia; Plenum Press: New York, NY, USA, 1989.

26. Kaneuchi, C.; Benno, Y.; Mitsuoka, T. Clostridium coccoids, a new species from feces of mice. Int. J. Syst. Bacteriol. 1976, 26, 482-486.

27. Stadtman, E.R.; Stadtman, T.C.; Pastan, I.; Smith, L.D.S. Clostridium barkeri sp. n. J. Bacteriol. 1972, 110, 758-760.

28. Min, B.; Kim, J.R.; Oh, S.E.; Regan, J.M.; Logan, B.E. Electricity generation from swine wastewater using microbial fuel cells. Water Res. 2005, 39, 4961-4968.

29. Kotsopoulos, T.; Fotidis, I.A.; Tsolakis, N.; Martzopoulos, G.G. Biohydrogen production from pig slurry in a CSTR reactor system with mixed cultures under hyper-thermophilic temperature $\left(70^{\circ} \mathrm{C}\right)$. Biomass Bioenergy 2009, 33, 1168-1174.

30. Zhao, Y.; Chen, Y.; Zhang, D.; Zhu, X. Waste activated sludge fermentation for hydrogen production enhanced by anaerobic process improvement and acetobacteria inhibition: The role of fermentation pH. Environ. Sci. Technol. 2010, 44, 3317-3323.

(C) 2015 by the authors; licensee MDPI, Basel, Switzerland. This article is an open access article distributed under the terms and conditions of the Creative Commons Attribution license (http://creativecommons.org/licenses/by/4.0/). 